\title{
The Rise and Fall of Labor Force Participation in the United States
}

James Bullard

Monetary policy choices going forward are explicitly tied to labor market performance. Hence, the sharp decline in the labor force participation rate following the 2007-09 recession has become a salient topic. Presented here are a summary of labor force participation rate data and projections, a survey of the literature that studies the recent decline in the participation rate, and a view toward fruitful paths for future research. (JEL E32, E52, J11, J21, J22)

Federal Reserve Bank of St. Louis Review, First Quarter 2014, 96(1), pp. 1-12.

$\mathbf{L}$ abor force participation in the United States has been a controversial subject in current macroeconomic discussions. In this article, I try to offer my own perspectives on the issue.

The participation rate-a measure of the number of people actively involved in labor markets-has generally been a secondary concern in macroeconomics. However, with recent sharp declines following the financial crisis and recession of 2007-09, it has suddenly become a salient topic, and one that gets discussed even in non-economic settings.

At its broadest level, the debate about the labor force participation rate is a debate about the nature of the U.S. economy over the $4 \frac{1}{2}$ years since the end of the recession, in the summer of 2009. Should we characterize the economy as substantially back to normal after a very severe recession? Or has little progress really been made, so that the economy remains far from its potential?

There are clear lines of argument on both sides, sometimes blurring political boundaries. Some suggest that the extraordinary policy response since the end of the recession has been largely ineffectual, perhaps citing the very flat employment-to-population ratio since 2009, ${ }^{1}$ and that their own suggested policy responses would have produced better outcomes. Others emphasize the risk associated with the extraordinary policy response, perhaps citing the Fed's now $\$ 4.1$ trillion balance sheet and the nation's relatively high debt-to-gross domestic product (GDP) ratio. Still others argue that the economy has recovered as well as can be expected in the wake of a major financial crisis, perhaps citing a recovery in real consumption expendi-

James Bullard is president and CEO of the Federal Reserve Bank of St. Louis. An earlier version of this article was delivered as a speech to the Exchequer Club, Washington DC, on February 19, 2014. The author thanks his staff for helpful comments.

(c) 2014, The Federal Reserve Bank of St. Louis. The views expressed in this article are those of the author(s) and do not necessarily reflect the views of the Federal Reserve System, the Board of Governors, or the regional Federal Reserve Banks. Articles may be reprinted, reproduced, published, distributed, displayed, and transmitted in their entirety if copyright notice, author name(s), and full citation are included. Abstracts, synopses, and other derivative works may be made only with prior written permission of the Federal Reserve Bank of St. Louis. 


\section{Figure 1}

\section{Unemployment Rate Before, During, and After the 2007-09 Recession}

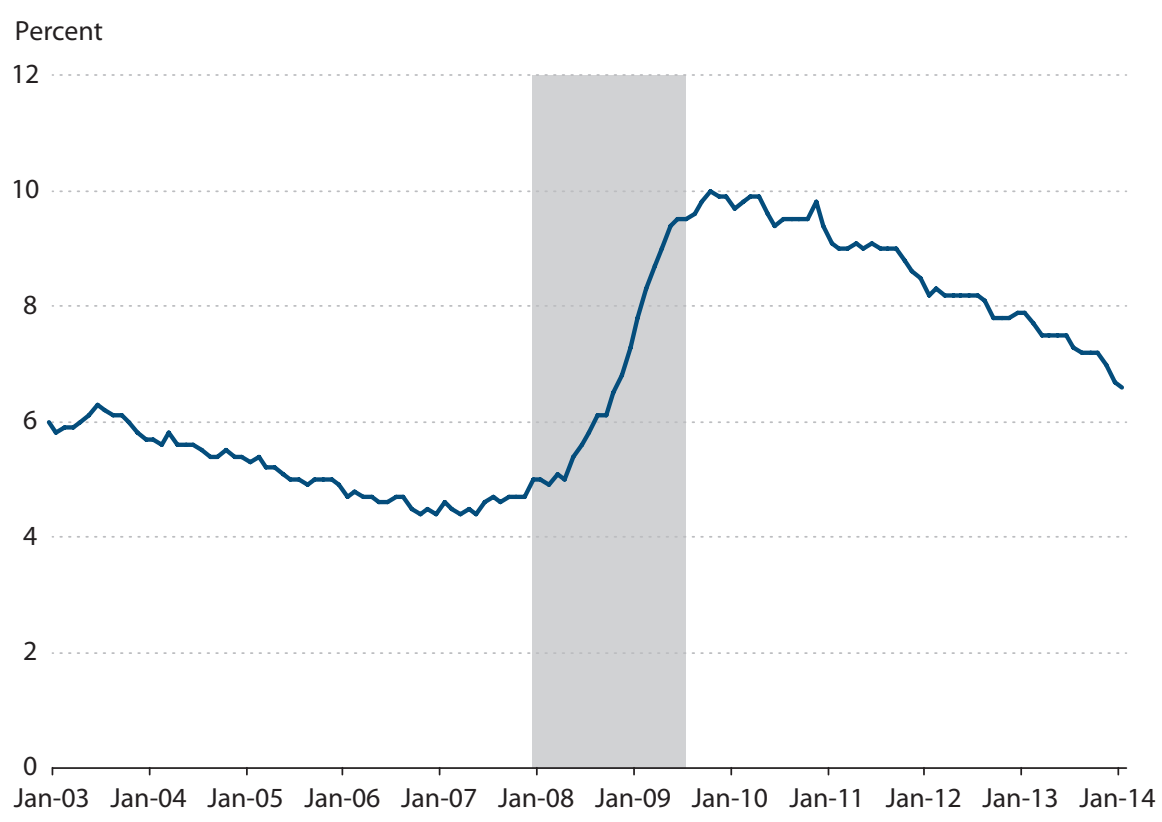

NOTE: The shaded bar indicates the 2007-09 recession as determined by the National Bureau of Economic Research. SOURCE: Bureau of Labor Statistics and National Bureau of Economic Research. Last observation January 2014.

tures, an improved housing market, a recovery in equity price valuations, and substantially lower unemployment. This last group might point to the euro area as an example of an economy that has suffered through a double-dip recession over the past several years, eventually leading to unemployment rates exceeding 12 percent, while the United States avoided this fate.

Labor market performance is at the heart of the debate over how to characterize the state of the U.S. economy. While unemployment in the United States was at 10 percent in the fall of 2009 (Figure 1), it has now declined to 6.6 percent according to the latest reading and has generally declined much faster than many forecasters anticipated. In tandem with this rosy development, however, there has been a substantial decline in labor force participation. Some say that the decline in labor force participation is a bad omen for U.S. macroeconomic performance, with labor market dropouts reflecting frustration with the state of the economy. I call this the "bad omen" view. Under this interpretation, the decline in the unemployment rate does not really reflect an improving labor market, and policymakers should look elsewhere to measure labor market outcomes. Others, however, argue that the decline in labor force participation simply reflects changing demographics in the U.S. economy and that different demographic groups have different propensities to participate in market work. As we have different numbers of people in these different demographic groups, we should naturally expect the aggregate labor force participation rate to change. I call this the "demographics" view. Under this inter- 
pretation, the unemployment rate remains about as good an indicator of overall labor market health as ever, and recent sharp declines in the unemployment rate should indeed be taken as indicative of an improving economy and an improving labor market.

In sum, the bad omen view interprets the recent declines in labor force participation as suggestive of a very weak labor market and discounts the signal coming from recent fasterthan-expected declines in unemployment. The demographics view interprets recent declines in labor force participation as more benign and takes the signal coming from recent faster-thanexpected declines in unemployment at face value. Since the Federal Open Market Committee (FOMC) has explicitly tied monetary policy choices to labor market performance, it is of considerable importance which view is more nearly correct.

I offer three perspectives on these questions. First, I simply summarize the data on labor force participation and provide some background on why this variable has suffered in relative obscurity until now. Second, I summarize my views on some of the available literature concerning labor force participation as it exists today. In my opinion, this literature is generally supportive of the demographics view, although there are different strands and many issues are not satisfactorily resolved. Third, I discuss the future of research in this area, which is to move to more-sophisticated approaches to labor force participation. The more-sophisticated class of models might be based on the so-called home production literature. Without going into the details of this approach, I believe that future progress in this area must become more serious about the incentives of households to supply labor to market work versus nonmarket work. ${ }^{2}$

\section{THE LABOR FORCE PARTICIPATION RATE}

The concept of labor force participation divides the population into three groups: employed, unemployed, and out of the labor force. This last group could also be called "nonparticipants" because they are neither working nor searching for market work.

The labor force participation rate is a ratio. In the numerator is the labor force, the sum of all persons employed and persons unemployed. We think of this group as participants in the market workplace. Many have jobs, and the rest are looking for jobs. In the denominator is the civilian noninstitutional population 16 years of age or older-that is, a generally accepted collection of everyone who conceivably could be working.

Here are some round numbers to keep in mind. The employed group is currently on the order of 145 million people. The unemployed group is on the order of 10 million people. And the nonparticipant group is on the order of 91 million people. The groups vary greatly in size; in particular, the nonparticipant group is large relative to the unemployed group. ${ }^{3}$ One quirk of organizing the data this way is that people routinely report moving from nonparticipation to market work without reporting themselves as unemployed. In other words-at least officially - they were not working and were not searching for a job but nevertheless ended up working at a job in the next reporting period. Evidently, they were not really properly categorized as "nonparticipants." I have always found this to be an unsatisfactory aspect of this method of data organization. 
Figure 2

\section{Labor Force Participation Rate}

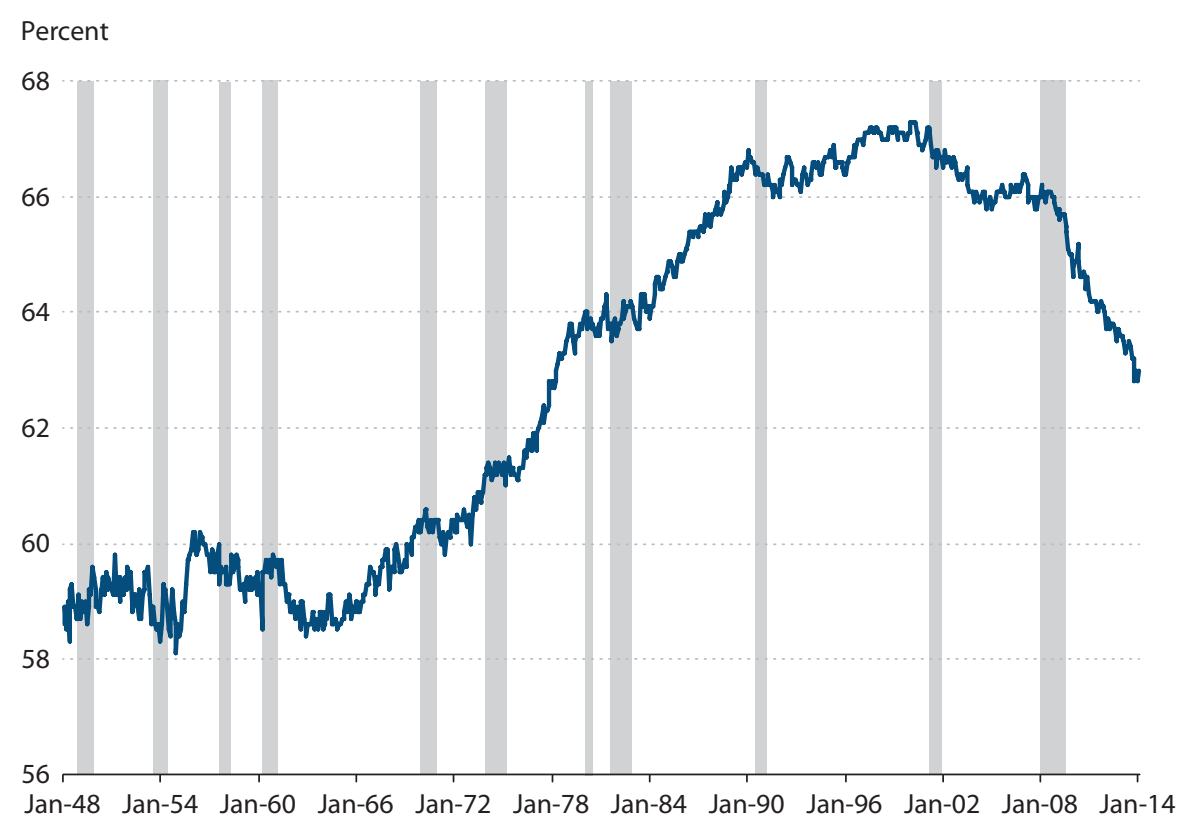

NOTE: The shaded bars indicate recessions as determined by the National Bureau of Economic Research.

SOURCE: Bureau of Labor Statistics and National Bureau of Economic Research. Last observation January 2014.

Many discussions of contemporary unemployment forecasts focus on the extent to which nonparticipants will rejoin the labor market. During the late 1990s, for example, many workers seemed to come off the sidelines into the workplace because of an exceptionally strong economy. At the Federal Reserve Bank of St. Louis, we have constructed unemployment forecasts in recent years assuming that movements from nonparticipation to employment would be minimal while unemployment was at relatively high levels. This has served us well, as we have more accurately predicted declines in unemployment in the past year than many other forecasters. ${ }^{4}$

If you know only one aspect of the data on labor force participation, it should be this: Labor force participation used to be relatively low. It rose during the 1970s, 1980s, and 1990s; peaked in 2000; and has generally been declining since 2000 (Figure 2).

From 1948 to 1966, the labor force participation rate was relatively low and relatively stable, averaging 59.1 percent-substantially lower than today's value of 63 percent. It is important to note that we normally consider the U.S. economy to have performed relatively well during this period, especially during the long expansion of the 1960s. Evidently, low labor force participation does not equate with weak economic growth. Surely this is because the factors driving economic growth differ from those driving labor force participation. 
After about three decades of trending upward, the labor force participation rate peaked in the first half of 2000 at 67.3 percent. The rate of increase was slower in the 1990s than in the 1970s or 1980s. The peak was more than 8 percentage points higher than the average level during 1948-66. Many labor force participation studies during this period focused on the increasing participation rates of women. However, whatever effects came from that source, or any other source, the labor force participation rate could not continue to increase forever. Households make choices about how much labor to supply given current wages and work environments, and women newly joining the labor force would find the right level of participation and stop there.

Since 2000, the labor force participation rate has generally been declining. The pace of decline was particularly sharp during the 2007-09 recession, but the participation rate also declined steadily in the early 2000s and since the end of the recession in mid-2009.

The general picture, then, is one of a hump shape in U.S. aggregate labor force participation during the postwar era. A satisfactory theory must account for this hump shape. One way to build such a theory is to appeal to demographics. The nation's workforce had a younger profile as the Baby Boom generation came of age, and it will have an older profile as the Baby Boom generation continues to retire. Since different age groups have different propensities to participate, this suggests a promising avenue to explain the labor force participation data.

I daresay that the demographic explanation is the gut instinct of many macroeconomists. This is why labor force participation sits in the backseat of many macroeconomic models. Many, including me, might reason that a good demographic model combined with more women in the labor force during the 1970s, 1980s, and 1990s could explain a very large fraction of the hump-shaped movements in aggregate labor force participation over the postwar era. If such a model were fitted to the data, only a small amount of variation in the participation rate would remain to be explained. That small remaining amount of variation might be attributable to business cycle (cyclical) effects, or it might just be noise about the fundamental hump-shaped trend. Relatively minor cyclical effects on labor force participation would likely be too small to have major macroeconomic implications given everything else going on in a macroeconomic model. Consequently, it might seem that we do not need to worry too much about the labor force participation rate for business cycle purposes.

But all this is just in the heads of macroeconomists. I now turn to some of the recent research on labor force participation to determine the extent to which such a theory has actually been devised.

\section{RECENT RESEARCH ON LABOR FORCE PARTICIPATION}

Let's start with the Bureau of Labor Statistics (BLS). The BLS is, of course, very close to the data and it routinely projects labor force participation over the medium term. In general, its medium-term forecasts from the mid-2000s proved to be too high, meaning that its forecast labor force participation rate was considerably higher than the values actually observed. More recent medium-term BLS forecasts call for a declining rate of participation over the next decade or so, all the way down to 61.6 percent in 2022 (Figure 3 ). ${ }^{5}$ Recall that today's participation rate 


\section{Figure 3}

\section{Labor Force Participation Rate: BLS Data and Projections}

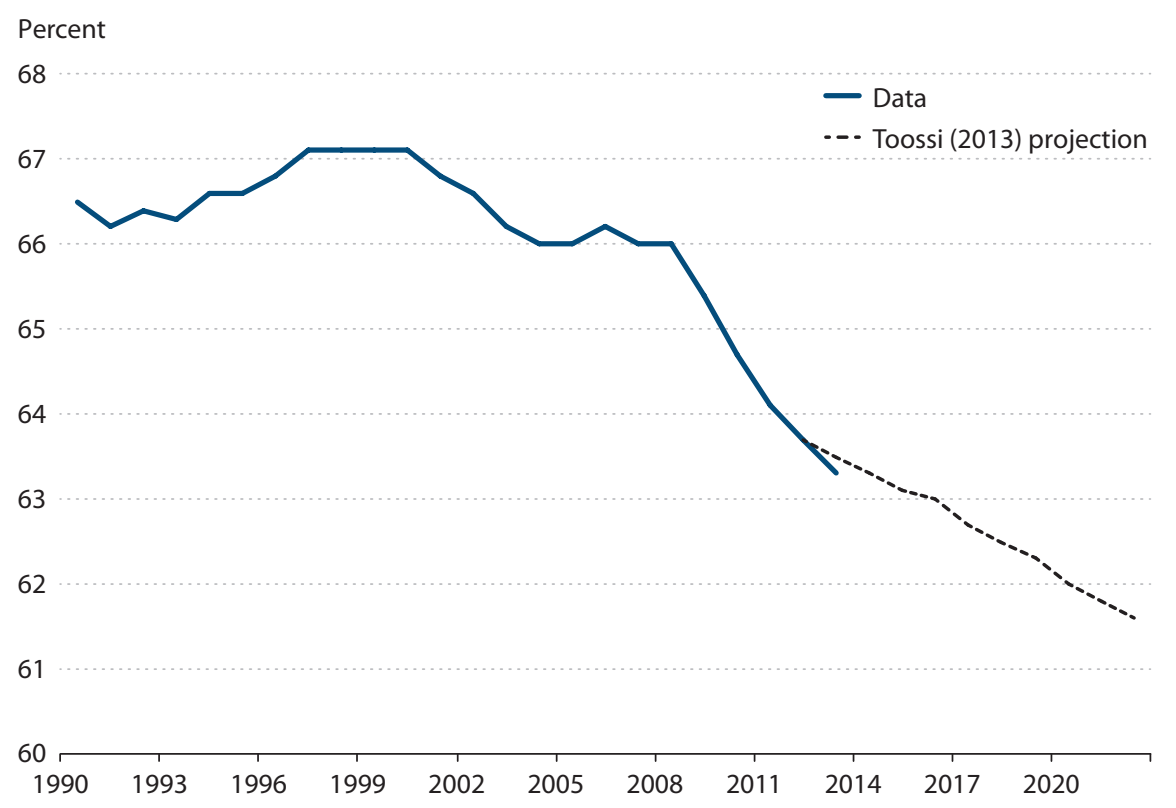

SOURCE: Bureau of Labor Statistics and Toossi (2013). Last observation 2013.

is 63.0 percent, so the rate is projected to continue to decline by around 15 basis points per year. According to BLS projections, ${ }^{6}$ more than 70 percent of this decline is due to purely demographic factors-that is, changes in population shares by age groups, assuming unchanged participation rates for each group. ${ }^{7}$

To the extent that this forecast pans out, the basic direction for the labor force participation rate is down, not up. Those waiting for an upward swing in labor force participation as the economy continues to expand will be disappointed, on average, if this forecast comes to pass. I read the BLS work as supportive of the demographics hypothesis I described previously.

Fujita (2013) provides some additional insight concerning the decline in aggregate U.S. labor force participation since 2000. Fujita's calculations suggest that about 65 percent of the decline in the participation rate was due to retirements and disability. Fujita points out that the empirical evidence suggests members of these groups have only a small probability of returning to the labor force. If we limit attention only to a period of relatively high economic stress, such as 2007:Q1 to 2011:Q2, we do see more of the decline in participation attributable to discouraged workers; but, even then, this is only about 25 percent according to Fujita's calculations. Over a less stressful period, such as 2012:Q1 to 2013:Q2, the entire decline in the aggregate labor force participation rate is attributable to retirements, with no effect at all coming from an increase in discouraged workers. I read Fujita's contribution as also supportive of the demographics hypothesis. 


\section{Figure 4}

\section{Labor Force Participation Rate: BLS Data and Aaronson et al. (2006) Projections}

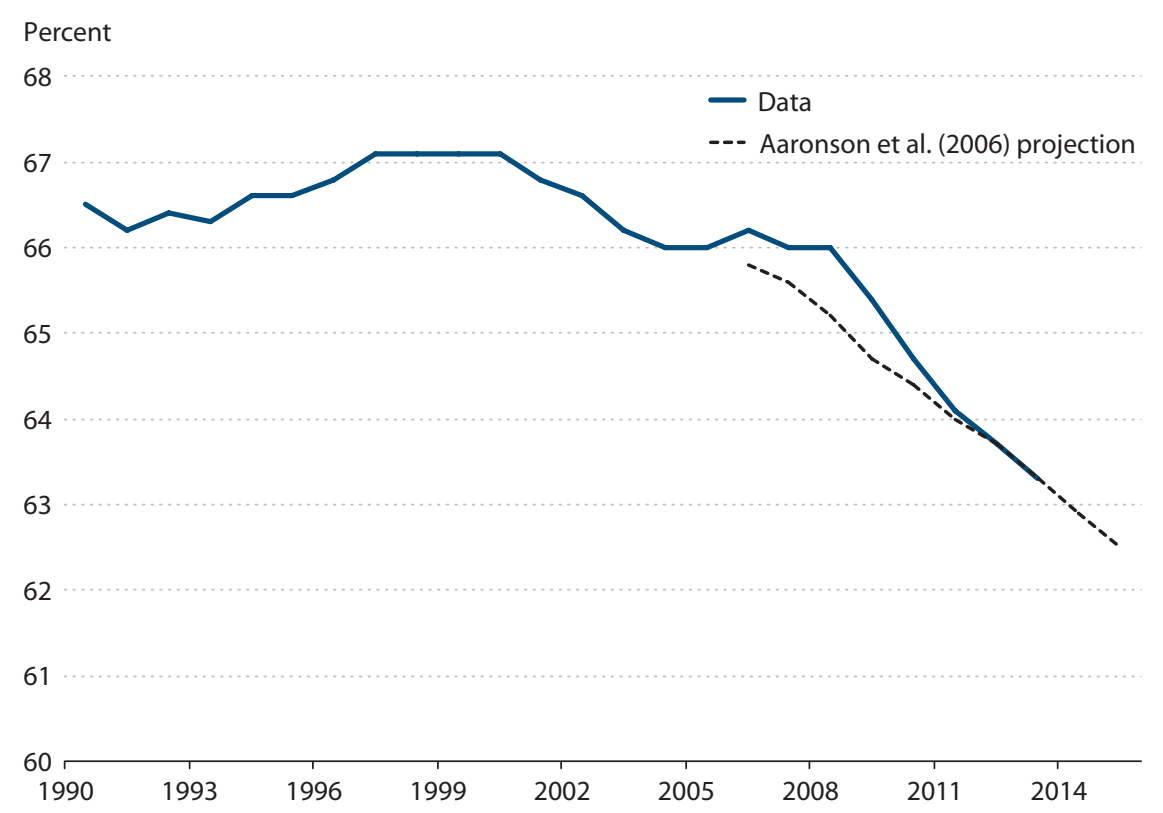

SOURCE: Bureau of Labor Statistics and Aaronson et al. (2006). Last observation 2013.

Davig and Mustre-del-Río (2013) provide some analysis of the "shadow" labor supply to gain insight into whether this group is likely to return to the labor force. The shadow group is defined as those who want a job but are not actively seeking one. The authors document that this group is demographically similar to the unemployed. They suggest that any impact on aggregate labor force participation from this group is likely to be small, because flows from this group to unemployment are small and less likely to occur as the recovery continues. I read this as also supportive of the demographics view.

In a somewhat older paper, Aaronson, Fallick, Figura, Pingle, and Wascher (2006) examined the decline in labor force participation following the 2001 recession and tried to ascertain how much of the decline at that time was cyclical. It is perhaps important to recall that there was an earlier debate on declining labor force participation, long before the deep recession of 2007-09. Their paper contains as part of the analysis an empirical model of the trend labor force participation rate that includes demographic factors. If that trend model is projected forward to today from 2006, it predicts nearly exactly the labor force participation rate observed in 2012 and 2013 (Figure 4). What a great piece of out-of-sample forecasting! I read this as supportive of the demographics view. This model also projects continued decline in the labor force participation rate in the years ahead.

Kudlyak (2013) follows up on the empirical model proposed by Aaronson et al. (2006). Again, the model contains key demographic information such as age, gender, and birth-year 
cohort effects. The model suggests that current aggregate labor force participation rates are not far off from the model's predicted trend participation rate. Again, I read this as supportive of the demographic view. ${ }^{8}$

Erceg and Levin (2013) study the intersection between the labor force participation rate and monetary policy. Their paper is a "thinking outside the box" exercise. In what I have presented so far, there is a certain inevitable logic. I stated that the data on labor force participation cry out for an explanation based mostly on increasing labor force participation by women and slowly changing demographics. The existing literature more or less provides such an explanation. Erceg and Levin instead ask whether there are other ways to think about this issue. They present evidence from U.S. states on prime-age males and suggest that the declines in labor force participation after the 2007-09 recession for this particular group were mostly cyclical. The authors then ask how monetary policy might be conducted in a world where labor force participation has an important cyclical component. They suggest that the participation decision should receive more attention in monetary policy research, a point on which I will agree below.

I do not find the evidence on cyclical versus structural changes in labor force participation in Erceg and Levin (2013) as persuasive as the other empirical work I have reviewed. ${ }^{9}$ Labor force participation for prime-age males, for instance, has also been on a secular decline for many years. Nevertheless, Erceg and Levin's points about how to conduct monetary policy in a world with important cyclical components in labor force participation are well made. ${ }^{10}$ In fact, I will argue that incorporating home production in economic models-as Erceg and Levin do-is where the future lies.

Some authors report somewhat higher estimates of the fraction of the decline in labor force participation since 2000 due to cyclical factors. For instance, Aaronson, Davis, and $\mathrm{Hu}$ (2012) use still another empirical model with demographic factors included and conclude that more than half of the decline in aggregate labor force participation from 2000 to 2011 is due to cyclical factors. Van Zandweghe (2012) tries an alternative method of decomposing the data from 2007 to 2011 and concludes that more than half of the decline is cyclical. The approach used by Hotchkiss and Rios-Avila (2013) emphasizes nonlinear factors following the severe 2007-09 recession; these authors conclude that nearly all of the decline in aggregate labor force participation following the recession was cyclical. Bengali, Daly, and Valletta (2013) study the correlation in the changes in employment and labor force participation in state-level data to gain insight; they conclude that a substantial cyclical component exists in the observed aggregate decline in labor force participation.

I am not necessarily swayed by these alternative approaches or results. But they certainly do show that there are many ways to cut the data and interpret the findings. This leads me to my final remarks - namely, where should the literature on labor force participation go next?

\section{HOME PRODUCTION AS THE FUTURE}

So far, I have reviewed some interesting economic literature on a topic that has been hot, not just among economists, but also among politicians, the media, financial markets, and even others who are not normally close students of macroeconomic developments. Much of the literature I have reviewed uses the same basic idea: Certain demographic groups have a 
certain propensity to participate in market work, and one of the main things we need to do as economists is project the number of people in each of these groups to determine a reasonable estimate of the expected (or "normal" or "trend") labor force participation rate in the U.S. economy. Much of the literature concludes that demographics have contributed substantially to the observed decline in U.S. labor force participation since 2000.

Still, most of the literature I reviewed is a bit hollow. Simply saying that people in certain demographic groups tend to make the participation decision one way or another does not do enough to analyze the incentives of household labor supply decisions. The more we know about the details of the household labor supply choices, including choices to participate in market work, the better we can predict the impact of policy on labor force participation. Furthermore, we would like these decisions to be part of the macroeconomic model, as Erceg and Levin (2013) suggest. ${ }^{11}$

There is one strand of the literature that does provide a more complete picture of household incentives to supply labor and participate in labor markets: the literature on so-called home production. We need not go into the details here, but the idea is simple. Think of a household as the owner of capital and labor. The household members combine their home capitalrefrigerators, ovens, dishwashers, cars, houses - with their labor time to produce home goods, such as a trip, a meal, or some child care. ${ }^{12}$ These goods are not acquired in the market and are not counted in GDP, but they matter to the household. The home labor provided does not count in the aggregate statistics on labor supply. The household then has to make decisions about how much time to supply to market work versus work at home, including how many members of the household should participate in market work. ${ }^{13}$ If we were to add to a household production model more explicit treatment of household retirement decisionmaking, in addition to decisions by younger households to acquire human capital, we would get to a more complete model of the labor force participation rate.

This approach is much more detailed regarding household decisionmaking than the research described above. But the extra complexity comes with a benefit, as the approach also allows macroeconomists to better understand the factors driving household labor supply decisions in terms of actual options inside the home, as well as with respect to the informal labor market. More-detailed models in this direction will likely be necessary in the future if we want to move the debate on labor force participation forward. ${ }^{14}$

Some researchers have made progress in this direction. Tripier (2004) analyzes a real business cycle version of the Diamond-Mortensen-Pissarides search and matching model that incorporates a home production decision. Tripier concludes that such a model has counterfactual implications for the unemployment and participation rates, while it can account for the behavior of the employment rate over the business cycle. Veracierto (2008) confirms these counterfactual implications in a richer model with endogenous job-acceptance and job-separation decisions. Tüzemen (2012) extends Tripier's analysis to allow for on-the-job search and, hence, job-to-job transitions. This model performs better in matching the business cycle features of the major labor market variables. 


\section{CONCLUSION}

While the unemployment rate has declined in recent years, labor force participation has also been declining, perhaps suggesting that unemployment is not as reliable an indicator of macroeconomic performance as it may have been in the past. Here I have given three perspectives on labor force participation: First, I reviewed the data; second, I reviewed the literature; and third, I suggested directions for future research.

The post-WWII data on aggregate U.S. labor force participation show a hump-shaped pattern. Participation rose in the 1970s, 1980s, and 1990s before peaking in 2000 and heading into decline up until the present day. Current BLS projections suggest that this decline will continue over the coming decade. The rise in labor force participation is often attributed in part to the maturing of the Baby Boom generation, as well as to the increase in the number of women in the workforce. The decline has often been attributed to the aging of the U.S. labor force. A satisfactory model has to account for the rise and fall over many decades. A demographically based model would seem to have a good chance of success in explaining these data.

I reviewed some of the available literature on this topic. My view of the literature is that carefully constructed, demographically based empirical models of the hump-shaped trend in the U.S. labor force participation rate do a good job of explaining the data. These models suggest that the current participation rate is not far from the predicted trend. This means, in turn, that the cyclical component in labor force participation is likely to be relatively small. To the extent these models are correct, then, the observed unemployment rate remains as good an indicator of overall labor market health as it has been historically. In particular, the recent, relatively rapid declines in unemployment can be understood as representing an improving labor market. This is the judgment that should inform monetary policy going forward.

The literature is not completely satisfactory, however. I discussed how researchers might gain additional insight by including more detailed household decisionmaking inside economic models. This would allow us to better understand what motivates or deters labor force participation. I look forward to seeing future research pushing in this direction. 


\section{NOTES}

1 For a recent analysis of the employment-to-population ratio as a labor market indicator, see Kapon and Tracy (2014).

2 Tripier (2004), Veracierto (2008), and Tüzemen (2012) take important steps in this direction.

3 See Canon, Kudlyak, and Reed (2014) for an analysis of the relative magnitude of the flows to employment from unemployment and nonparticipation.

4 See Bullard (2014).

5 See Toossi (2013).

6 Author's calculation based on figures from Toossi (2013).

7 For more on this topic, see Canon, Debbaut, and Kudlyak (2013).

8 A forthcoming working paper by Hornstein and Kudlyak (2013) includes a more elaborate version of this model. Their main finding remains that current labor force participation rates are close to what would be predicted by an empirical model with carefully constructed demographic factors.

9 For more on this issue, see Canon, Debbaut, and Kudlyak (2013).

${ }^{10}$ I also largely agree with the points made by Orphanides (2013) in a comment on the paper, in effect that the new labor market slack indicators proposed by Erceg and Levin would be subject to considerable uncertainty and could lead policymakers badly astray.

${ }^{11}$ For an example of a detailed macroeconomic model with an explicit participation decision that has an impact on policy recommendations, see Imrohoroğlu and Kitao (2012).

${ }^{12}$ Time use surveys, such as the American Time Use Survey (ATUS) conducted by the BLS, provide a wealth of data to quantify labor supplied to home production. For example, see Aguiar and Hurst (2007).

${ }^{13}$ For an example of the different perspective the home production literature provides on issues in monetary economics, see Aruoba, Davis, and Wright (2012).

${ }^{14}$ For an example of the interplay between home production and labor force participation, see Greenwood, Seshadri, and Yorukoglu (2005).

\section{REFERENCES}

Aaronson, Daniel; Davis, Jonathan and Hu, Luojia. "Explaining the Decline in the U.S. Labor Force Participation Rate." Federal Reserve Bank of Chicago Chicago Fed Letter, No. 296, March 2012; http://www.chicagofed.org/digital_assets/publications/chicago_fed_letter/2012/cflmarch2012_296.pdf.

Aaronson, Stephanie; Fallick, Bruce; Figura, Andrew; Pingle, Jonathan and Wascher, William. "The Recent Decline in the Labor Force Participation Rate and Its Implications for Potential Labor Supply." Brooking Papers on Economic Activity, Spring 2006, 37(1), pp. 69-134; http://www.brookings.edu/ /media/projects/bpea/spring\%202006/2006a_bpea_aaronson.pdf.

Aguiar, Mark and Hurst, Erik. "Measuring Trends in Leisure: The Allocation of Time over Five Decades." Quarterly Journal of Economics, August 2007, 122(3), pp. 969-1006; http://www.jstor.org/stable/25098866.

Aruoba, S. Boragan; Davis, Morris A. and Wright, Randall. "Homework in Monetary Economics: Inflation, Home Production, and the Production of Homes." NBER Working Paper No. 18276, National Bureau of Economic Research, August 2012; http://www.nber.org/papers/w18276.

Bengali, Leila; Daly, Mary and Valletta, Rob. “Will Labor Force Participation Bounce Back?" Federal Reserve Bank of San Francisco Economic Letter, 2013-14, May 13, 2013;

http://www.frbsf.org/economic-research/publications/economic-letter/2013/may/will-labor-force-participationbounce-back/.

Bullard, James. "Ghosts of Forecasts Past and Future." Remarks delivered at the Indiana Bankers Association Economic Outlook Forum Luncheon, Indianapolis, IN, January 10, 2014; http://research.stlouisfed.org/econ/bullard/pdf/Bullard-IN-Bankers-Association-January-10-2014-Final.pdf. 
Canon, Maria; Debbaut, Peter and Kudlyak, Marianna. "A Closer Look at the Decline in the Labor Force Participation Rate." Federal Reserve Bank of St. Louis Regional Economist, October 2013, 21(4), pp. 10-11; http://www.stlouisfed.org/publications/pub_assets/pdf/re/2013/d/labor_force.pdf.

Canon, Maria; Kudlyak, Marianna and Reed, Marisa. “Not Everyone Who Joins the Ranks of the Employed Was 'Unemployed."' Federal Reserve Bank of St. Louis Regional Economist, January 2014, 22(1), pp. 14-16; http://www.stlouisfed.org/publications/pub_assets/pdf/re/2014/a/unemployed.pdf.

Davig, Troy and Mustre-del-Río, José. "The Shadow Labor Supply and Its Implications for the Unemployment Rate." Federal Reserve Bank of Kansas City Economic Review, Third Quarter 2013, pp. 5-29; http://www.kc.frb.org/publicat/econrev/pdf/13q3Davig-Mustre.pdf.

Erceg, Christopher J. and Levin, Andrew T. "Labor Force Participation and Monetary Policy in the Wake of the Great Recession." IMF Working Paper No. 13/245, International Monetary Fund, July 2013; http://www.imf.org/external/pubs/ft/wp/2013/wp13245.pdf.

Fujita, Shigeru. "On the Causes of Declines in the Labor Force Participation Rate." Federal Reserve Bank of Philadelphia Research Rap Special Report, November 2013; revised February 6, 2014; http://philadelphiafed.org/research-and-data/publications/research-rap/2013/on-the-causes-of-declines-in-thelabor-force-participation-rate.pdf.

Greenwood, Jeremy; Seshadri, Ananth and Yorukoglu, Mehmet. "Engines of Liberation." Review of Economic Studies, January 2005, 72(1), pp. 109-33; http://restud.oxfordjournals.org/content/72/1/109.full.pdf+html.

Hornstein, Andreas and Kudlyak, Marianna. "Estimating the Trend in the LFP Rate." Federal Reserve Bank of Richmond, forthcoming working paper, December 2013.

Hotchkiss, Julie L. and Rios-Avila, Fernando. "Identifying Factors behind the Decline in the U.S. Labor Force Participation Rate." Business and Economic Research, June 2013, 3(1), pp. 257-75; http://www.macrothink.org/journal/index.php/ber/article/view/3370/2921.

Imrohoroğlu, Selahattin and Kitao, Sagiri. "Social Security Reforms: Benefit Claiming, Labor Force Participation, and Long-Run Sustainability." American Economic Journal: Macroeconomics, July 2012, 4(3), pp. 96-127; http://www.aeaweb.org/articles.php?doi=10.1257/mac.4.3.96.

Kapon, Samuel and Tracy, Joseph. "A Mis-Leading Labor Market Indicator." Federal Reserve Bank of New York Liberty Street Economics (blog), February 3, 2014;

http://libertystreeteconomics.newyorkfed.org/2014/02/a-mis-leading-labor-market-indicator.html.

Kudlyak, Marianna. "A Cohort Model of Labor Force Participation." Federal Reserve Bank of Richmond Economic Quarterly, First Quarter 2013, 99(1), pp. 25-43;

http://www.richmondfed.org/publications/research/economic_quarterly/2013/q1/pdf/kudlyak.pdf.

Orphanides, Athanasios. "Discussion of 'Labor Force Participation and Monetary Policy in the Wake of the Great Recession' by Erceg and Levin." Delivered at the Federal Reserve Bank of Boston 57th Economic Conference Fulfilling the Full Employment Mandate, April 2013.

Toossi, Mitra. "Labor Force Projections to 2022: The Labor Force Participation Rate Continues to Fall." Monthly Labor Review, December 2013, pp. 1-28;

http://www.bls.gov/opub/mlr/2013/article/pdf/labor-force-projections-to-2022-the-labor-force-participationrate-continues-to-fall.pdf.

Tripier, Fabien. "Can the Labor Search Model Explain the Fluctuations of Allocations of Time?" Economic Modelling, January 2004, 21(1), pp. 131-46; http://www.sciencedirect.com/science/article/pii/S0264999302000871.

Tüzemen, Didem. "Labor Market Dynamics with Endogenous Labor Force Participation and On-the-Job Search.” Working Paper No. 12-07, Federal Reserve Bank of Kansas City, October 2012; http://www.kansascityfed.org/publicat/reswkpap/pdf/rwp12-07.pdf.

Van Zandweghe, Willem. "Interpreting the Recent Decline in Labor Force Participation." Federal Reserve Bank of Kansas City Economic Review, First Quarter 2012, pp. 5-34; http://www.kc.frb.org/publicat/econrev/pdf/12q1VanZandweghe.pdf.

Veracierto, Marcelo. "On the Cyclical Behavior of Employment, Unemployment and Labor Force Participation." Journal of Monetary Economics, September 2008, 55(6), pp. 1143-57; http://www.sciencedirect.com/science/article/pii/S0304393208000998. 